Research Report No. 22/2009

\title{
Law and Learning in an Era of Globalization
}

Harry W. Arthurs

Osgoode Hall Law School of York University, harthurs@osgoode.yorku.ca

Follow this and additional works at: http:/ / digitalcommons.osgoode.yorku.ca/clpe

\section{Recommended Citation}

Arthurs, Harry W., "Law and Learning in an Era of Globalization" (2009). Comparative Research in Law \& Political Economy. Research Paper No. 22/2009.

http://digitalcommons.osgoode.yorku.ca/clpe/135 


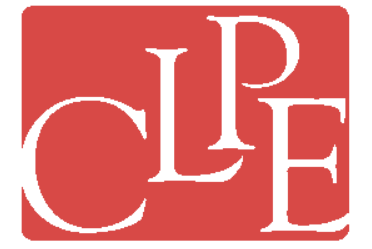

\section{Comparative Research in Law \& Political Economy}

CLPE RESEARCH PAPER 22/2009

Harry W. Arthurs

Law and Learning in an Era of Globalization

EDITORS: Peer Zumbansen (Osgoode Hall Law School, Toronto, Director, Comparative Research in Law and Political Economy, York University), John W. Cioffi (University of California at Riverside), Nassim Nasser (Osgoode Hall Law School, Toronto, Production Editor)

Also available at: http: / /www.germanlawjournal.com 



\section{German Law Journal}

Law and Learning in an Era of Globalization Harry W. Arthurs

10 German Law Journal 629 (2009), available at:

http://www.germanlawjournal.com/article.php?id=1111

This article was originally published in Volume 10, Number 7 of the German Law Journal as part of the journal's $10^{\text {th }}$ anniversary symposium on "Transnationalizing Legal Education" edited by Nadia Chiesa, Adam de Luca, and Bernadette Maheandiran. 
CLPE Research Paper 22/2009

Vol. 05 No. 04 (2009)

\title{
Harry W. Arthurs
}

\section{LAW AND LEARNing IN AN ERA OF GLOBALIZATION}

\begin{abstract}
This paper explores the ways in which globalization, as a dominant influence on political economy, makes its presence felt on legal education and research. In particular, it questions whether law schools have maintained agency in the choice to embrace globalization in their curricula, scholarship and general orientation or whether law schools have been forced to bend to the realities of the global economy. While neo-liberal "globalization of the mind" has shifted assumptions about the project of law and entrenched a "new normal" in legal education and scholarship, the McGill curriculum - based on so-called "transsystemic" legal education offers the promise of professional and intellectual formation based on law's radical indeterminacy in an era of globalization, neo-liberalism and law "without the state".
\end{abstract}

Keywords: Legal education, Globalization

JEL classification: K10, K40

Harry W. Arthurs

University Professor emeritus and

President emeritus, York University.

Email: harthurs@osgoode.yorku.ca. 



\title{
SPECIAL ISSUE: TRANSNATIONALIZING LEGAL EDUCATION
}

\section{Law and Learning in an Era of Globalization}

\author{
By Harry W. Arthurs*
}

\section{A. Introduction}

The optimists amongst us assume that human hands - our hands - shape legal education, that legal education shapes the law, and that law shapes the world. The pessimists contend that the process works in reverse, that the forces of political economy ultimately have their way with law as a system of social ordering, as a cultural phenomenon and an intellectual enterprise, and as the subject or object of study in law schools. I am a pessimist by nature, so I will begin on a pessimistic note. However, I am trying to overcome my nature, so I will end on what, for me, is an optimistic one. ${ }^{1}$

\section{B. Legal Education, Political Economy and Globalization}

Governments pass laws, enter into treaties, appoint judges, establish tribunals, oversee officials and police, and shape or respond to public attitudes concerning immigration, antisocial behaviour, the environment, and many other issues. They regulate the involvement of citizens with the legal system by adjusting the balance between social control and individual freedom of action, by opening or closing avenues for complaints and claims and by juridifying or de-juridifying citizens' encounters with the machinery of the state. They

\footnotetext{
*University Professor emeritus and President emeritus, York University. Email: harthurs@osgoode.yorku.ca. This paper was originally delivered as the keynote address at the Learning and Law Annual Conference, United Kingdom Centre for Legal Education, University of Warwick, 4 January 2007. It appears in this symposium issue of the German Law Journal with the kind permission of the UK CLE and its director, Dr. Julian Webb. I acknowledge as well the insightful critique of an earlier draft provided by Roderick Macdonald and the research assistance of Scott Jones and Claire Mummé.

${ }^{1}$ More accurately, perhaps, I am trying to recover the optimism I demonstrated in SOCIAL SCIENCES AND HUMANITIES Research Council of CANADA, LAW AND LeARning / Le dRoIt et le SAVOIR: Report of the Consultative Group on Research AND EdUCATION IN LAW (1983) (also known as "the Arthur's Report"), which eroded badly in my subsequent writings, see e.g. Harry Arthurs, The Political Economy of Canadian Legal Education 25 JOURNAL OF LAW \& SOCIETY (J. Law \& Soc.) 14 (1998); Harry Arthurs, Poor Canadian Legal Education: So Near to Wall Street, So Far from God, 38 Osgoode Hall LAW JouRnal (OHU) 381 (2001); Harry Arthurs, The State We're In: Legal Education in Canada's New Political EConomy, 20 WINDSOR YEARBOOK OF ACCESS TO JUSTICE 35 (2001).
} 
influence the market for legal services by regulating the legal profession's monopoly, providing funds for legal aid, hiring lawyers in the civil service and engaging private practitioners to perform legal work on their behalf. Their influence on law, and hence on legal education, is pervasive. However, governments act not in a vacuum but within a range of possibilities defined by the forces of political economy. In that sense, I claim, political economy ultimately determines the content of the law school curriculum, the attitudes and assumptions law students bring to their studies, the judgments and books which find their way onto law school syllabi and the research agenda of legal academics.

Nor do governments - and the forces of political economy - influence legal education only by indirection. They set higher education policies, establish the structure of legal education, license educational providers, provide funds for law faculties, impose fees on law students, require legal academics to meet quality standards in their teaching and research, and measure the success of law schools in recruiting top students and improving the job prospects of their graduates.

My pessimist's conclusion, to reiterate, is that political economy does much to determine the ends and means of legal education and research. And because globalization is a dominant influence on political economy, it becomes the 800-pound gorilla whose presence in our deliberations we can hardly avoid.

The question is: "how, exactly, will that gorilla make its presence felt?" In one sense, the answer is as obvious as the gorilla itself. Globalization alters the material circumstances of states and of groups and communities within states. This restructuring of the economy leads to the reconfiguring of the market for legal services. In the United Kingdom, the decline of the industrial economy and the rise of one based on information technology and financial services has led directly to the decline of High Street law practices which serve small, local businesses and to the growth of large, city firms which serve a global clientele. In Canada, ever-closer integration into a North American economic space dominated by the United States has realigned our economic and political elites and, inevitably, our legal elites as well. The result in both countries is not only specific changes in legislation, doctrine, procedures and institutions directly affected by the new economy. It is a more general redistribution of power and prestige within the legal profession; a new emphasis on what the profession and its regulators view as "relevant" knowledge, valued skills and exemplary behaviour; and of course a revised sense amongst legal academics of what it is important for us to be teaching and writing about.

A quick tour of law school websites and calendars supports my hypothesis that globalization has become a dominant theme. Some law schools have declared themselves "global law schools", adopted a "global curriculum", hired a "global faculty", established research centres on "global law" and entered "global partnerships" with foreign 
institutions. ${ }^{2}$ Others have begun to offer courses on globalization and the law, on global governance, global lawyering and global security - amongst many other "global" offerings. ${ }^{3} \quad$ Many have introduced global perspectives into conventional courses, acting either on the initiative of interested faculty members or as the result of explicit academic planning decisions. ${ }^{4}$ Law school conferences, books written by legal academics, even legal periodicals published by law schools are devoted entirely to exploring the impact of globalization on law. ${ }^{5}$ It is no coincidence that with the advent of globalization, some of our best students decide to seek careers with global law firms or that some of our best scholars focus their research efforts on influencing the outcome of global legal issues.

So globalization is a prominent new feature of legal education and scholarship. ${ }^{6}$ But does this prove the optimists right or the pessimists? Does it demonstrate that law schools have retained agency, that their new, global curricula, syllabi, pedagogies, staffing strategies and

2 E.g. Hauser Global Law School (NYU - US); National Law School of Singapore; University of Navarra (Spain); Jindal Global Law School (India) amongst many others.

${ }^{3}$ E.g. Melbourne Law School (Australia); Warwick Law School (UK), Osgoode Hall Law School of York University (Canada); Universidade Catolica (Portugal); Rutgers Law School (US) amongst many others.

${ }^{4}$ E.g. Craig Scott, A Core Curriculum for the Transnational Legal Education of JD and LLB Students: Surveying the Approach of the International, Comparative and Transnational Law Program at Osgoode Hall Law School, 23 PENN State International LaW ReVIeW (Penn St. INT'L L. ReV.) 757 (2005); Thomas Alexander Aleinikoff, Law in a Globlal Context: Georgetown's Innovative First Year Program, 24 PENN ST. INT'L. L. REV. 825 (2006); John E. Sexton, Curricular Responses to Globalization, 20 PENN ST. INT'L L. REV. 15 (2001-2002); Nancy B. Rapoport, When Local IS Global: Consortium of Law Schools to Encourage Global Thinking, 20 PENN. ST. INT'L L. REV. 19 (2001-2002); Larry Cata Backer, Parallel Tracks?: Internationalizing the American Law School Curriculum in Light of the Principles in the Carnegie Foundation's Educating Lawyers, available on SSRN at http://papers.ssrn.com/sol3 papers.cfm?abstract_id=1104098, last accessed 14 June 2009; Duncan Bentley and John Wade, Special Methods and Tools for Educating the Transnational Lawyer, 55 JourNAL OF LEGAL EdUCATION (J. LEGAL EDUC.) 479 (2005); Michael Bogdan, Is There a Curricular Core for the Transnational Lawyer? 55 J. LEGAL EdUC. 484 (2005); for a description of a British school's ventures in global law teaching, see the description of University College London's Institute for Global Law at http://www.ucl.ac.uk/laws/global_law/, last accessed 14 June 2009 - amongst many others.

5 Over a dozen conventional and online law-related English-language journals appear to be devoted entirely to the theme of globalization: Canadian Journal of Globalization; Global Law Review; Globalization; Global Social Policy; Human Rights and Globalization; Indiana Journal of Global Legal Studies; Journal of Global Ethics; Journal of Globalization, Competitiveness and Governability; Law, Social Justice and Global Development; Minnesota Journal of Global Trade; Richmond Journal of Global Law and Business; Washington University Global Studies Law Review. In addition numerous legal journals devoted to international and transnational law, as well as those without specialized mandates, are replete with articles on globalization.

${ }^{6}$ Of course, globalization is not altogether a new influence on legal education: British imperial legacies shaped the governments, economies, legal systems and universities of its ex-colonies; the Catholic educational and juristic traditions of France and Spain left their mark on the law faculties of Québec and Latin America; and American legal education and scholarship, in its many manifestations, has influenced the development of law schools throughout (and beyond) the English-speaking world since at least the late $19^{\text {th }}$ century when the United States began its economic and political ascendancy. I am grateful to Roderick Macdonald for calling my attention to this important point. 
research agendas are the result of a conscious choice to embrace globalization? Or does it confirm that law schools have indeed been forced to bend to the new realities of a global political economy?

\section{Globalization of the Mind and its Implications for Law and Legal Education}

Being a pessimist by nature, I tend to the latter view. My own sense is that we are experiencing what I call "globalization of the mind". Globalization is associated not only with a change in our material circumstances and relationships, and not just with the adaptation of public policy, legal practice and legal education to new patterns of economic activity. Rather, globalization involves a change in our social values, and in our fundamental understandings about what role law does play and should play in society. Globalization is, in other words, an ideology.

Beneath this ideology lies a bedrock assumption: that governments, which interfere with the free flow of goods, services, capital and information (but not people) impair their capacity to maintain a dynamic economy. There may be good reasons to question this assumption, and to reject the conventional wisdom; but to do so requires a degree of daring possessed by few governments, not including yours or mine. Instead, most focus on creating a business-friendly environment by deregulating markets, decreasing corporate taxes and privatizing certain public services. Such policies represent a significant reversal of the vaguely social-democratic impulse that dominated public policy making during the postwar period. Government then was meant to get involved in order to make things better; government now is meant to step aside for fear of making things worse.

My point is not that neo-liberal globalization is an unmitigated evil and that social democracy is an "unqualified human good". Rather it is that globalization of the mind neo-liberal globalization of the mind - has helped to accomplish a fundamental shift in assumptions and values, and to entrench a "new normal" in legal education and scholarship.

The assumptions and values of this "new normal" can be summarized as follows: the transnational trumps the national; markets trump politics; law's mission is to make the world safe for markets; and finally, the best kind of law is law which permanently constitutionally - disables the state's capacity for regulatory intervention. In all these respects, the "new normal" is very different from the "old normal" of the Keynesian welfare state. Consequently, I think one can fairly say that Thatcher's children - the students, lawyers and academic staff who came of age intellectually and professionally in the nineties - inhabit an ideological universe which differs from that of their predecessors, who came of age in the sixties or the thirties. The assumptions about that universe which they bring to their classrooms, common rooms and chambers, the optic within which they view legal issues, the scope and focus of their legal imaginations, what 
they write as law teachers or read as law students, how they define themselves as legal actors: in all these respects, Thatcher's children have distanced themselves ideologically from their forbears. Globalization - considered not just as political economy but as ideology - accounts in large measure for that distancing.

Of course some of Thatcher's children have become rebellious. They have chosen to struggle against the prevailing political economy, to reject the "new normal" ideology of neo-liberal globalization, and to work for a world in which states and politics retain their importance, and in which markets are a fact of life, but not an end in themselves. Some of these rebellious children challenge globalization and neo-liberalism in all its manifestations. Some focus on specific issues of gender, race, poverty and the environment. And some - bless them - even believe that law is a useful strategy to achieve social justice. However, I am afraid that increasing numbers of legal actors legislators, judges, senior civil servants, policy wonks, lobbyists, lawyers, legal academics and editorial writers - simply regard a globalized version of neo-liberal capitalism as the first principle of every nation's unwritten constitution.

This new constitutional grundnorm has a number of consequences, but I will mention only four.

First, and perhaps the most important, is that we have consciously or unconsciously adopted a particular version of the rule of law that emphasizes the protection of economic interests against encroachments by the state, rather than guaranteeing individuals their political rights, access to public goods or defence against abuses of private power. You'll all recall William Twining's legendary encounter with a student in Khartoum, who couldn't get the point of a torts case because he couldn't understand what a camel was doing in the London Zoo. ${ }^{7}$ It will seem no less odd to future readers of the law reports that state law should once have been invoked by workers to protect their right to join unions, by poor persons to claim social benefits or by government agencies to regulate bus fares, land use or foreign exchange transactions.

Another consequence is that while today's law students and staff may still feel at home with domestic legislation and judicial pronouncements, their successors are likely to feel more comfortable with global legal institutions, doctrines and processes. To be sure, some of these will have been established through state action, but many will owe their origins to initiatives by transnational businesses, discursive and professional communities, NGOs and sectoral associations which set standards, settle disputes, impose sanctions, generate meaning, propagate values and confer legitimacy.

\footnotetext{
${ }^{7}$ WiLlaAm TWINING, The Camel in the Zoo, in LAW In CONTEXT: ENLARGING A DisCIPLINE, 26 (1997).
} 
This brings me to a third sense in which "globalization" is having a profound effect on the way in which law is perceived, produced and consumed, with knock-on consequences for legal scholarship and education. According to William Scheuerman, "the process of spacetime compression" associated with globalization "raises many fundamental questions for legal scholarship". ${ }^{8}$ Scheuerman argues that globalization, together with technological change, has reshaped the constitutional matrix within which the three branches of government perform their functions. ${ }^{9}$ It has disabled the legislature which cannot legislate in derogation of free trade, let alone debate in any serious way the detailed regimes by which foreign and domestic economic activity is to be regulated. This in turn has enhanced the power of the executive branch, which typically enjoys an open-ended parliamentary mandate to negotiate trade regimes, and to make critical decisions concerning fiscal and economic policies. And, he argues, it has enlarged the role of the judicial branch, which referees boundary disputes between the other two.

In a parallel development, established relations between central and regional governments have been upset by powerful tendencies set in motion by globalization. The survival of local cultures is threatened by transnational cultural flows; resource-based local economies are destabilized by the uncontrolled fluctuations of global commodity prices; subventions and supports provided by national governments to stimulate local industries and economies are vulnerable to attack as illicit trade subsidies. The result, understandably, is often local resentment, sometimes accompanied by calls for local autonomy or even secession and, at the least, for a veto by regional governments over decisions concerning culture, immigration, industrial policy and foreign trade. To the extent that states like Canada and the UK respond to these calls by shifting powers from the centre to the regions, globalization will have brought about a very substantial change in the structures of governance.

But not only is globalization effectively amending the constitutions of states by triggering the redistribution of powers amongst the different branches and levels of government, it is also subjecting national governments to entirely new constitutional constraints. Institutions of the European Union (EU) have acquired power to strike down, rewrite or mandate the enactment of national legislation, while non-governmental tribunals have acquired power under global economic treaties such as the World Trade Organization (WTO) or North American Free Trade Agreement (NAFTA) to neutralize or invalidate the laws of member states. International agencies such as Interpol, the World Bank and the

\footnotetext{
${ }^{8}$ William Scheuerman, Reflexive Law and the Challenge of Globalization, 9 Journal OF Political PHILOSOPHY 81, 91 (2001).

${ }^{9}$ William SCHEUeRMAN, Liberal DEMOCRACY AND tHE SOCIAL ACCELERATION OF TIME (2004).
} 
World Health Organization (WHO) now share responsibility with national governments for forestalling or responding to terrorism, economic perturbations, pandemics and environmental catastrophes. So too do private security firms, airlines, banks, hedge funds and drug companies.

Fourth and finally, globalization has effectively de-coupled the idea of law from the idea of the state. Of course, for some time now the assumption that state and law are intrinsically and invariably linked has been questioned by legal pluralists and other socio-legal scholars. However, their work has been largely driven by case studies of law in pre-modern communities, and in modern or post-modern businesses, neighbourhoods and workplaces. Because these non-state legal systems exist prior to the arrival of state law, or subject to its let and tolerance or in its shadow, they could be dismissed as merely pathological or aberrational, as not challenging the notion that states alone can and do make "real" law. However, recent studies of transnational corporations, commercial networks and business transactions seem to provide incontrovertible evidence that "law without the state" prevails even - perhaps especially - in the most privileged precincts of global business, finance, communications and transport.

Once we acknowledge that non-state normativity plays an important role in key areas of the economy, we will have to learn to accept its importance in other contexts as well. This is likely to precipitate a major crisis in legal education. If states do not after all enjoy a monopoly over the making, promulgation, administration and enforcement of law, law teachers and law students will have to start using a new mental map to navigate ordinary courses in contracts, criminal law, labour law and family law. And to do so, they will need a new repertoire of intellectual skills. After all, by whatever means we have traditionally taught students to "think like lawyers", we will have to do something different to teach them not to think like lawyers - or at least not like the lawyers we've been training up to this point. Instead of parsing judicial decisions, for example, they may have to peruse arbitration awards or observe mediators at work; instead of reading legislation, they may be asked to scrutinize corporate codes of conduct or consult ethnographic studies; and instead of being taught to fetishize fairness, rationality, predictability and clarity as law's contribution to social ordering, they may find themselves learning to value pragmatism, imagination, flexibility and ambiguity.

In summary, the merest scrutiny of law office dockets, law journal indices and law school syllabi will reveal that neo-liberal globalization has redefined the very concept of law itself, redrawn the map of law-making and law enforcement, revised legal practice and discourse and reconfigured legal scholarship and pedagogy. 


\section{The De-coupling of Law and State: The Rise of Trans-systemia}

You may be disconcerted by this description of the likely future of legal education following the advent of the "new normal" and the decentering of the state. If so, you will be even more disconcerted by my next statement: "I have seen the future and it works". The first person to make such a claim in those precise words was apparently an American journalist, Lincoln Steffans, on the occasion of his return in 1921 from a protracted visit to the Soviet Union. The future that Steffans saw most assuredly didn't work, as he himself soon acknowledged. However, the future I have glimpsed - while no less revolutionary is definitely more benign and possibly more long lasting. I refer to the new curriculum of McGill law school, in Montreal.

\section{Transsystemic Legal Education at McGill}

McGill decided about ten years ago, after a remarkably sophisticated and welldocumented debate, to implement a unique polyjural or trans-systemic curriculum. ${ }^{10}$ That is to say, individual courses and the curriculum as a whole consciously integrate civil and common law perspectives, domestic and international perspectives, the perspectives of state law and of non-state legal systems, and legal perspectives with those of other disciplines. Incidentally, all of this is done in both of Canada's official languages.

McGill's trans-systemic curriculum reflects, builds upon and reinforces the strong research interests of its staff in comparative and international law, legal pluralism, discourse analysis and intellectual history as well as in socio-legal fields such as sustainable development and medical ethics. Not by coincidence, these research interests all raise questions about the role of the state and of state law, and they do so in all the four senses I have mentioned, in light of globalization and neo-liberalism, and through the optic of inter-disciplinarity and legal theory. And, also not by coincidence, McGill is an English speaking university located in Quebec, a French-speaking province or (some say) "nation", where the character and identity of the state have been hotly debated for the past half century, and where trans-, sub- and non-state systems of law have flourished.

I want to make clear that McGill is not merely training law graduates for global law firms and enterprises, international agencies, transnational NGOs or other employers who might wish to hire young lawyers who are fluent in several languages and legal vernaculars. While many of its graduates do end up in just such careers, the architects of the new curriculum would strenuously deny that they were trying to prepare students to practice law in what they ironically refer to as "trans-systemia".

\footnotetext{
${ }^{10}$ The curriculum and its intellectual foundations and implications are described in a special issue of the McGILL LaW Journal (MCGILL L. J.) titled "Navigating the Transsystemic / Tracer le Transsystemique" released in 2005 (issue 50, volume 4, pages 701 - 1006), available online http://lawjournal.mcgill.ca/issues.php, last accessed 14 June 2009.
} 
What then do they think they are doing? Clearly, McGill is attempting first and foremost to problematize the very notion of law itself. One former dean argues that the McGill law curriculum treats law as simply "a way of being alive" ${ }^{11}$ Another claims that it is designed to bring students into "a sustained and humble dialog [sic] with otherness". ${ }^{12}$ The present dean insists that the curriculum requires students to explore "what explains law as a social phenomenon, what is the nature of legal knowledge, what does it mean to think like a lawyer, [and] what it means to think like a citizen alive to law's symbolic and persuasive attributes". ${ }^{13}$

Of course, McGill's deans are not the only ones to articulate their faculty's ambitions in such expansive, if Delphic, terms. Most legal academics would say that they want to take their distance from conventional understandings of law. However, McGill deserves special mention because it has so directly and explicitly taken up the challenge of thinking about legal education "without the state". This is not to say that McGill's curriculum is perfect, that it succeeds in its own terms, or even that the curriculum on McGill's books resembles the curriculum in practice. ${ }^{14}$ Nor would I argue that other faculties of law can or should imitate McGill. Indeed, I am not going to talk about the actual experience of legal education at McGill, but rather about the McGill curriculum understood as an ideal-type, as a thought experiment in what might happen to legal education in this era of globalization, neo liberalism and "law without the state".

Because the McGill curriculum is trans-systemic, it challenges the notion that law's logic is bounded, its values fixed, its processes ascertainable, and its outcomes predictable. Law in the McGill curriculum does not arrive on students' laptops neatly encoded according to juridical family or conceptual category. Instead, legal systems and categories collide with and penetrate each other, reinforce and refute each other, in unpredictable ways. Civil or common law, religious or secular law, domestic or international law, state law or some other kind, all form part of the open-textured, complex, heterogeneous normative universe which students must learn to inhabit. Law, for the McGill student, is therefore found not only in statute books and law reports; it is found everywhere, inscribed in private documents, embedded in custom, extruded from transactions or experienced as conventions of discourse and routines of daily life. Indeed, as claimed, the McGill curriculum - by acknowledging the infinite varieties of "law" - underscores the need for

\footnotetext{
${ }^{11}$ Roderick Macdonald quoted in Nicholas Kasirer, Bijuralism in Law's Empire and in Law's Cosmos, 52 J. LEGAL EDuc. 29, 39 note 2 (2002).

${ }^{12}$ Yves-Marie Morissette, McGill's Integrated Civil and Common Law Program, 52 J. LEGAL. Educ. 12, 22 (2002).

${ }^{13}$ Kasirer, supra, note 11 at 31.

${ }^{14}$ For my own modest reservations see Harry Arthurs, Madly Off in One Direction: McGill's New Integrated, Polyjural, Transsystemic Law Programme, 50 McGILL L. J. 707 (2005) (part of the special issue mentioned in supra, note 10).
} 
a "dialog with otherness". It denies students the comfort of the familiar: it asks them to imagine law as if they were someone else. Even law's connection with justice cannot be taken for granted by McGill law students; law sometimes empowers, sometimes oppresses and sometimes seems to do not much at all. This is a curriculum, in short, which assumes law to be radically indeterminate. At McGill, to reiterate, law is "a way of being alive".

\section{Teaching in Transystemia}

A curriculum built on the premise of law's radical indeterminacy may be exhilarating for us as legal scholars; but for us as legal pedagogues, it poses great challenges. In this last section of my talk, I want to explore those challenges.

The first has to do with what our students want from us. Meeting student expectations today is more important than we might prefer, given that the financial wellbeing of our law schools depends increasingly on our ability to persuade students to enrol here rather than there, to pay us significant fees and to incur debt to do so, and to signal their satisfaction by responding to surveys and making a success of their careers. And meeting student expectations is not only more important; it is more difficult, too, given that the "new normal" of the current generation of students puts them at odds with many of our own assumptions and values. Nonetheless, successful pedagogy requires that we somehow address student expectations - whether we meekly cater to them or boldly seek to change them.

What do law students want? They may begin with different career aspirations, bring different learning styles to the classroom and espouse different political views. But I would argue strongly that most law students want predictability. They want to see a clear point to their studies and a fixed purpose to their lives; they want structures, they want rules. They want, in other words, precisely what the McGill curriculum is designed not to give them.

How to square this circle? One way is to give them what they want. We all do this to some extent, and have developed standard justifications for doing so. Much of conventional legal life is in fact not that unpredictable, we tell ourselves: state law ends up punishing many if not most criminals, tortfeasors and contract breakers. State legal systems are not that permeable, truth to tell: quoting the Talmud, citing a Korean statute or relying on an ethnography of disputing in poor neighbourhoods will not win many victories in British or Canadian courtrooms. Justice isn't that irrelevant to legal rules or outcomes, we cheerfully acknowledge: if nothing else, impassioned appeals to justice have great potential to mobilize policy makers and persuade judges. And finally, agnosticism about the sustainability of law's empire isn't that useful as a pedagogic strategy; students too easily confuse it with cynicism. But for all that such concessions to student angst are warranted, they describe a strategy of "stoop to conquer". 
A second approach is somewhat more edifying. Law schools like McGill are able to engage in "niche marketing". That is, they try to ensure that the students they attract are those most likely to feel at home in the pedagogic environment they offer. There is much to recommend this approach. It is honest; it ensures that students and faculty share a sense of common purpose; and it helps to more closely align pedagogic philosophy and pedagogic practice. On the other hand, niche marketing has its drawbacks. It assumes that prospective students have adequate knowledge and can make meaningful choices; it represents an attempt to impose closure on an approach to law whose distinguishing characteristic is supposed to be its openness; and it smacks a bit of incest.

A third approach - far more difficult, but far more satisfying - is to engage students in serious conversations which will free them from the tyranny of rules. This requires that we adopt a certain posture in the classroom. First, we must give students confidence that their experiences of family and school, and their encounters with people, culture and work is somehow relevant to their legal studies. This will provide them with a vantage point from which to begin to question the wisdom dispensed by judges, legal texts and ourselves. Second, we have to convince them that despite our own comprehensive knowledge of law, sociology, philosophy, politics, economics, history, astrology, sport and sex, we still value questions more than answers. Third, we must show them how to use their newfound confidence not just to challenge the instructor and interrogate the materials being taught, but to dare to ask questions of themselves. And finally, we must help them get used to the fact that they are embarking on a course of study, and ultimately on a career, that will require them to live at ease with multiple truths, irresolvable conflicts, abundant ambiguities and ironies galore.

Whatever its other merits, it seems to me that the McGill curriculum is admirably designed for this last approach to teaching. It is - you will conclude and I will confess - my kind of curriculum and my kind of teaching. Does this - I ask you - make me an optimist after all? 
